\title{
ロケットノズルの過膨張時に生じる非対称流れに関する研究*
}

\author{
米澤宏一*1, 守本剛*2, 辻本 良信*3 \\ 渡 邊 泰 秀*4, 横田 和 彦*5
}

\section{A Study of an Asymmetric Flow in an Overexpanded Rocket Nozzle}

\author{
Koichi YONEZAWA*6, Tsuyoshi MORIMOTO, Yoshinobu TSUJIMOTO, \\ Yasuhide WATANABE and Kazuhiko YOKOTA \\ ${ }^{* 6}$ Department of Mechanical Science and Bioengineering, \\ Graduate School of Engineering Science, Osaka University, \\ 1-3 Machikaneyama-cho, Toyonaka-shi, Osaka, 560-8531 Japan
}

\begin{abstract}
This paper presents about an investigation of unsteady three-dimensional flows in an overexpanded rocket nozzle during the shutdown transient. The experimental and numerical investigations are performed. It has been known that, in some case, an asymmetric flow induces the serious lateral force called "side load" during transient operation. The focus of the present paper is the clarification of the characteristics of asymmetric flow patterns during shutdown transient. Each result obtained by measurements and computation shows qualitative agreement. The flow pattern becomes asymmetric during the transition of the separation pattern from restricted shock separation (RSS) to free shock separation (FSS) and result in a large and impulsive side load. Additionally, during the transition, a three-dimensional vortex structure is formed on the nozzle wall in the separation bubble.
\end{abstract}

Key Words: Nozzle, Transonic Flow, Separation, Numerical Analysis, Three-dimensional Unsteady Simulation

\section{1. 緒}

近年, 各国の大型ロケットのメインエンジンには, 様々な形状の超音速ノズルが用いられるようになっ た。ロケットノズルには，従来，ノズル出ロで速度分 布が一様となる Perfect ノズルの下流部分を切断した Truncated Perfect (TP)ノズルが広く用いられてきた. TP ノズルは比推力などの性能面で優れ，また，故障 につながるような大きな問題点もほとんど報告され ていない．しかし，TP ノズルの欠点としては，ノズ ルの全長が長いことが挙げられる。このことは, エン ジンや機体の設計に制約を加える他，ロケットエンジ ンに対する要求として非常に重要な要素である, 小型 化・軽量化の面では大きな障害となる.このため, ヨ ーロッパの Ariane V ロケットの Vulcain エンジンなど には Thrust Optimized (TO)ノズルと呼ばれる形状のノ ズルが用いられ, 日本の H-IIA ロケットのメインエン ジン LE-7A には Compressed Truncated Perfect (CTP) ノズル(1)が用いられている.

* 原稿受付 2005 年 7 月 27 日.

*1 正員, 大阪大学大学院基礎工学研究科(-560-8531 豊中市 待兼山町 1-3).

*2 学生員, 大阪大学大学院基礎工学研究科,

*3 正員, フェロー, 大阪大学大学院基礎工学研究科。

*4 宇宙航空研究開発機構 ( $\mathbb{3} 891$-3793 鹿児島県熊毛郡南種子 町大字茎永字麻津)

*5 正員, 名古屋工業大学大学院ながれ領域 (-466-8555 名古 屋市昭和区御器所町).

E-mail : yonezawa@me.es.osaka-u.ac.jp
しかし,これらの新型形状が用いられるようになる と, 新たに大きく分けて 2 つ問題が生じるようにな った．第 1 の問題はエンジンの起動・停止時に生じる ノズルの振動であり，第 2 の問題はノズル内壁を構成 する再生冷却チューブが高熱負荷により一部破損す る現象である。これらの問題の発生原因は, TO ノズ ルや CTP ノズルで生じる特殊なはく離形態であるこ とが報告されている(2)(3). 図 1(a)に示すはく離形態は Free Shock Separation (FSS) と呼ばれる形態で，TP ノ ズルや円錐型ノズルをはじめ, TO ノズルや CTP ノズ ルなど, 多くの形状で発生する一般的なはく離形態で ある.FSS の特徴は, 衝簐波-境界層干涉によりはく 離した超音速ジェットが, はく離点下流でノズル壁面 に再付着することなく, ノズル外部に流出しているこ とである.一方, 図 1(b)に示すはく離形態は Restricted Shock Separation (RSS)と呼ばれる形態で, TO ノズル や CTP ノズルなどの一部の形状にのみ発生する特殊 な形態である. RSS は, はく離した超音速ジェットが はく離点のすぐ下流でノズル壁面に再付着するはく 離形態で, はく離点と再付着点との間には流れの循環 領域が作られる. また, 再付着点近傍の超音速ジェッ 卜内部には衝撃波が発生するので局所的に高圧・高温 の領域が形成される. Frey や Hagemann ら (2), (4)-(6)は, Vulcain エンジンを対象に，軸対称流れを仮定した 2 次元 CFD や縮小モデルによる実験, 実機の燃焼試験 


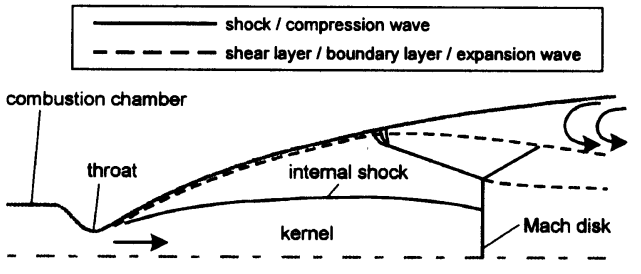

(a) Free shock separation (FSS)

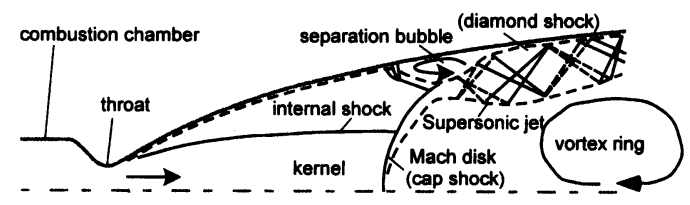

(b) Restricted shock separation (RSS)

Fig. 1 Separation pattern in overexpanded nozzle

を行った.そして，エンジンの起動・停止時において TO ノズル内部では FSS と RSS との間の遷移がごく短 時間で起こり，このとき，流れ場が非対称になること でパルス状の横力が発生し，ノズルが大きく振動する ことが明らかとなった. また, Watanabe ら ${ }^{(3)}$ は開発段 階の LE-7A エンジンの燃焼試験結果から, CTP ノズ ルでも同様に RSS の発生に伴いノズルが大きく振動 することに加えて, RSS 以外にもフィルム泠却用の段 差が横力の発生原因になることも報告している.また 開発段階の LE-7A ノズルにおいては RSS の発生に伴 いノズル壁面を構成する再生冷却チューブの一部が 破損し，末然の水素が漏油したことも報告されている.

以上のように RSS が発生することで超音速ノズル には多くの問題が生じる. 特にノズルの振動の原因と なる横力については前述のように多くの研究が行わ れてきた.この結果, RSS の発生機構や横力との関係 については多くの理解が得られてきている．しかし， これらの研究は, 実験や軸対称流れを仮定した 2 次元 数値計算によるものがほとんどで, ノズル内部の流れ 場の 3 次元構造についてはほとんど議論されておら ず, 非対称流れに関する詳細な調查は行われていない. 今後, ロケットエンジンの信頼性を向上させるために は，流れ場を詳細に把握することは不可欠であると考 えられる.そして流れ場を詳細に調べるためには 3 次 元数值計算が有効であると考えられる. 近年では清水 $ら^{(7)}$ が LE-7A ノズルの起動時に関する3 次元数値計算 を行い,フィルム冷却用段差が横力を発生させる機構 について調查した。 また Wang $^{(8)}$ も起動時に関する 3 次元計算を行っている. しかし， 3 次元計算を用いた 研究例は少なく，得られた知見は十分とは言えない.

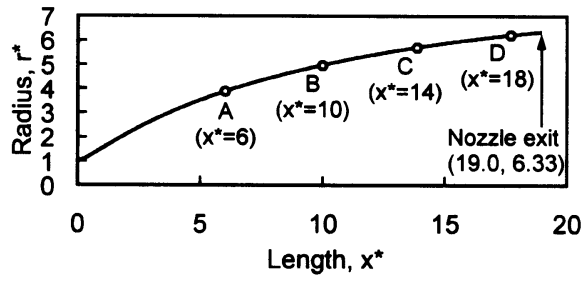

Fig. 2 Nozzle contour and pressure measurement points

そこで本研究はロケットノズルにおける過膨張流 れに関して,さらに知見を加えるために行った停止時 に関する実験, ならびに 3 次元非定常数値計算の結果 を報告する．なお，本来は実際のロケットエンジンと 同様に燃焼ガスを用いて研究を行うことが望ましい が, 本研究では, 基礎研究として流れの基本的な特性 のみに着目することとし，作動流体を空気とし，これ を理想気体として扱った。

\section{2. 主な 記号}

NPR : Nozzle Pressure Ratio (=入口圧力/背圧)

$r \quad:$ 半径方向位置

$x$ : 軸方向位置

( )* : スロート半径 $(5 \mathrm{~mm})$ で無次元化した值

\section{3. 实験装晴と数值計算法}

$3 \cdot 1$ ノスル形状 図 2 に本研究で用いたノズルの形 状を示す．本研究で用いたノズル形状は段面積比が 49.0の Perfect (比熱比 1.4 で設計)ノズルの長さを $75 \%$ に圧縮し, さらにスロート半径の 19 倍の長さで切断 した CTP ノズルとした. なお,このノズルに関する

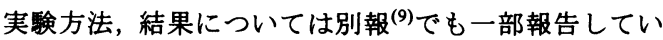
るので参照されたい. 実験では壁面圧力を計測したが, 軸方向には図中に示した A D の 4 点を計測点とした. 周方向については，A D のそれぞれの点を $90^{\circ}$ ごと に 4 点ずつ配置し，それぞれ A1, A2, ‥,D4 と呼ぶこ とにする.よってノズル壁面上には合計 16 点の圧力 計測点が配置されている.これ以降，スロート中心を 原点として，ノズルの軸方向の座標を $x$ 座標とする.

$3 \cdot 2$ 实験装百の概要 図 3(a)に本研究で用いた大気 吸い込み式風洞の模式図を示す. 実験はテストセクシ ョン・タンク内の圧力を $1 \mathrm{kPa}$ 以下に減圧し, 電磁バ ルブを解放することで停止時の流れ場を作り出して いる. また，テストセクション側面の観察空からはシ ユリーレン法による可視化を行い, ノズル出ロ近傍の 流れ場を可視化した. なお, 可視化結果は高速度力メ ラを用いて 13500FPS で記録した。また，図 3(b)に示 


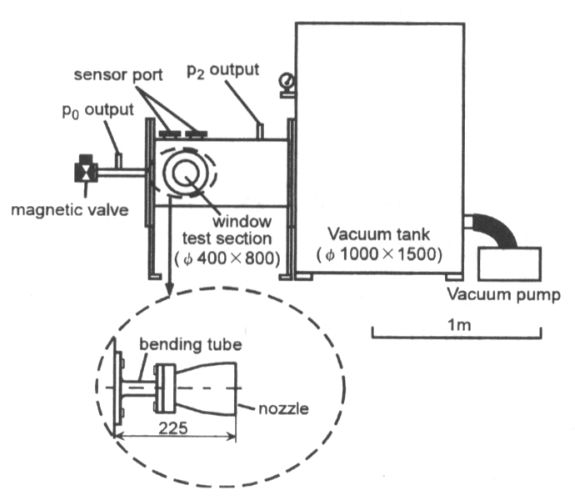

(a) Schematic of wind tunnel

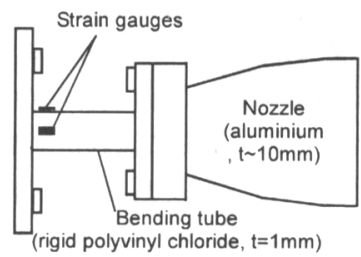

(b) Description of measurement system of side load torque Fig. 3 Experimental apparatus

すように,ノズルは硬質塩化ビニル製の管により支持 されており， $x^{*}=-22$ の位置にひずみゲージを貼付し ノズルの振動による管のひずみを計測した. 本試験装 置は大気を吸い込むため, 作動流体の密度が小さく, 横力も小さかったので, ノズルを支持する管として硬 質塩化ビニル管を用いても振動は微小であると仮定 できる，そして，横力の算出には Frey らの方法 ${ }^{(4)}$ を 用いた。すなわち，管をばね，ノズルを質点と考えて， 系を単振動系とみなし, 周波数応答 (変位伝達関数) を求めて, ひずみゲージの出力を横力 (モーメント) に変換した。 なお, 本研究で用いたノズルと管からな る采の固有振動数は約 $14.5 \mathrm{~Hz}$ であった。 また，停止 時のひずみデータをサンプリング周波数 $2 \mathrm{kHz}$ で計測 し, FFT 解析を行ったところ, およそ $400 \mathrm{~Hz}$ までの範 囲に微小ではあるがスペクトルのピークがいくつか 確認された。そこで, ひずみデータから横力データへ の変換は $500 \mathrm{~Hz}$ 以下の成分に限定した。 また,この 方法を用いると周波数が大きくなるほど微小なノイ ズ成分も増幅されてしまう。したがって, 絶対的な力 の大きさの正確な評価は難しいため, 横力については 計測值の最大值で無次元化し, 0.5 秒間毎の平均值を 用いて定性的な傾向のみを評価した。

実験の手順としては, まず, 壁面圧力計測と可視化 を同時に行った。ただし,この際はノズルの振動の影

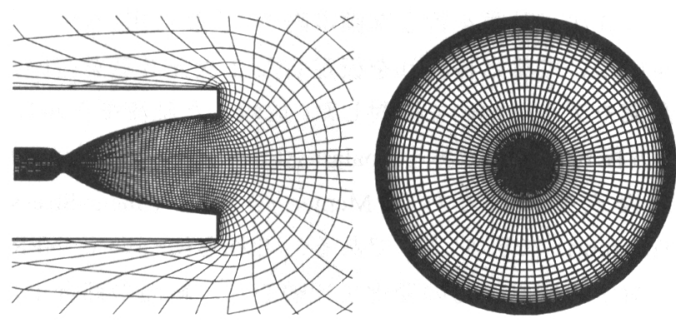

(a) Computational mesh

(Left: meridian section, right: cross section at nozzle exit)

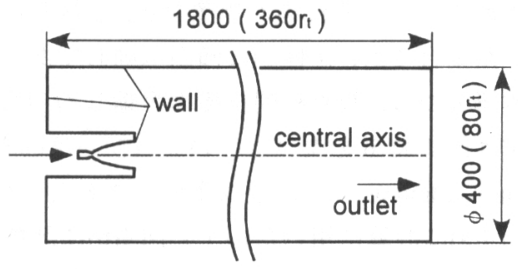

(b) Geometry of computational region ( $\mathrm{r}_{\mathrm{t}}$ : throat radius)

Fig. 4 Computational region

響を排するためにノズルを支持する管は厚さ $2 \mathrm{~mm}$ の アルミニウム製のものを用いた. 次に, 硬質塩化ビニ ル製の支持管に交換し, 横力のみを計測した.これは, ノズルに取り付けた圧力変換機がノズル外部の流れ により力を受け, 横力の計測が不可能であったためで ある、なお，実験は再現性を確認しながら複数回ずつ 行った.

$3 \cdot 3$ 数値計算法の概要 本研究では実験に対応する 条件で 3 次元非定常数值計算を行った。 なお, 用いた 計算機は HITACHI SR8000 (東京大学情報基盤センタ 一)で，領域分割法に基づく並列計算を 8 ノード(1) ードあたり8CPU)を用いて行った。 また,ノード間通 信にはMPI (Message Passing Interface)を用いた。以下 に, 本研究で用いた手法の概要を示す.

支配方程式は Favre 平均化された 3 次元 Navier-Stokes 方程式とし, これを有限差分法により保存則を満たす ように離散化して計算した. 対流項の流束分離法には AUSMDV ${ }^{(10)}$ を用い, さらに基本変数の 4 次精度 MUSCL 内插 ${ }^{(11)}$ を併用して精度を向上した。粘性項は 2 次精度中心差分により離散化した。時間進行は陰解 法を用いて行い, 2 次精度後退型 3 点差分で離散化し, 各時間刻みで sub-iteration を行い, 解を収束させた。 なお, 行列解法には LU-SGS 法 ${ }^{(12)}$ を用い, 各時間ステ ップでの時間刻み幅は $2.0 \times 10^{-6} \mathrm{~s}$ とした.

本研究で扱うような大規模なはく離を伴う流れの 数值計算では, はく離点の予測などに関して, 計算に 用いる乱流モデルが大きく影響する，そこで, 本研究 
では 3 次元計算を行う準備段階で, 実験に用いたノズ ルについて軸対称流れを仮定した 2 次元計算を行い, 乱流モデルについて検討した. 比較した乱流モデルは, 1 方程式モデルである Spalart-Allmaras モデル(13) と, 2 方程式モデルである Menter の SST (Shear-Stress Transport) モデル (14) である.これらについて NPR に対する壁面圧力の変化を比較した. 紙面の都合上, 結果は図示しないが, 各 NPR でのはく離点の位置や 壁面圧力分布を実験結果と比べた場合, 大きな差は確 認されなかった. また, はく離形態の変化や, その過 程で形成される流れ場の特徵など, どちらのモデルを 用いた場合でも，定性的な傾向は同じであった。 そこ で本研究では, 計算時間を極力短縮しつつも, 流れ場 の定性的な特徴を調べるという当初の目的を考えて, Spalart-Allmaras モデルを採用することとした.

図 4(a)に計算に用いた格子と図 4(b)に計算領域の模 式図を示す. 本研究では格子点数は計算時間を考虑し たうえで, 可能な限り多く用いることとし, 軸方向に 298 点(ノズル内部に 230 点), 半径方向に 70 点, 周方 向に 189 点(10 点は重ね合わせ) の合計 3,942,540 点を 用いた. なお, 計算領域の形状は, 直径 $800 \mathrm{~mm}$, 長 さ $1800 \mathrm{~mm}$ の円筒形の空間に, ノズルが設置された状 態となっている.これは風洞のテストセクションと同 一の直径を持ち, テストセクション全長とタンク直径 をあわせた長さとなっている. 図 4(b)に示した境界で, 以下に示す境界条件を用いた. ノズル入口境界は亜音 速流入条件とし, 全圧を $100 \mathrm{kPa}$, 全温 $290 \mathrm{~K}$ に固定し, Riemann 不変量を内点から外挿した. ノズル壁面とテ ストセクション内壁を表す壁面境界は全て断熱・ non-slip 壁として扱った. 計算領域右端の出口境界は 亜音速流出を仮定して静圧を与えた. 実験と同様, 停 止時に関する計算なので, 静圧は $1 \mathrm{kPa}$ から $10 \mathrm{kPa}$ ま で 0.1 秒間で線形的に変化させた。 ただし, 実験では $1 \mathrm{kPa}$ から $10 \mathrm{kPa}$ まで約 10 秒間で線形的に変化したが, 過去の報告例(15) などからも, 流れ場の変化はNPR で 整理することができ, 流れ場の変化の時間に対する依 存性は小さいと考えられるので, 定性的な議論を行う 上では, 計算時間を短縮するためにこのような条件を 用いても問題ないと考えられる.

初期条件としては, 全域が $1 \mathrm{kPa}, 300 \mathrm{~K}$ で静止した 状態から, 入口圧力を $0.01 \mathrm{~s} て ゙ ~ 1 \mathrm{kPa}$ から $100 \mathrm{kPa}$ まで 直線的に上昇させて起動時の流れを作り,さらに 0.02 秒間, 入口・出口の条件を固定して計算した結果を用 いた.

本研究で用いた格子形状や境界条件は計算精度の 範囲内で軸対称となるものを用い, 擾乱など非対称流
れを発生させる要素を意図的には与えていない. した がって流れ場の非対称性は, 数值誤差などが発端とな り, 流れ場の不安定性により発生するものである.

\section{4. 結果と考察}

$4 \cdot 1$ はく離形態の变化 図 5 にシュリーレン写真に よるノズル出口近傍の流れ場を示す. 図 5(a)に示す NPR が約 100 のとき, はく離形態はFSS となってお り, はく離したジェットは破線で示したノズル壁面か ら離れたところにある. しかし, 図 5(b)に示す NPR が約 80 のときには RSS へと変化し, ジェット外縁は ノズル壁面に沿うように外側へ移ったことがわかる. このとき, 可視化された映像からは, 流れ場の大きな 非対称性は確認されなかった. RSS が発生した後, さ らに NPR が小さくなると, 図 5(c)の図中に示すノズ ル出口よりやや下流の部分で流れが変動している様 子が見られたものの, ノズル出口付近では大きな乱れ は観察されなかった. 図 5(d)はRSS から FSS へ変化 する途中の写真である.このときには噴流外縁を表す 影が不鮮明になっており流れ場が乱れていることが わかる.ただし，このように噴流が大きく乱れ非対称 となっている時間は約 0.001 秒間と非常に短かった. 図 5(e)はFSS への変化が完全に終わった後の状態で ある.はく離したジェットが鮮明に確認でき, 流れ場 はほぼ対称に戻っていることがわかる. 以上のように， 本研究で行った実験では, NPR が約 80 から約 18 の 間に RSS が発生していた。

図 6 に数值計算により得られた結果を子午断面上 のマッハ等高線で示す. 図 6(a)に示す $N P R=100$, つま り初期条件下では流れはほぼ対称となっており,はく 離形態は FSS となっている. NPR が低下していくに したがってはく離点は上流へと移動し, NPR が約 40 で RSS へと変化した。この NPR の值は実験結果(約 80) と大きく異なっている，図 6(b)に示す RSS 一遷移 した直後の流れ場を見ると, 実験同様流れ場の非対称 性は小さい. NPR がさらに低下すると, 図6(c)のよう に衝撃波やはく離点は上流へと移動していく.このと きも, 衝波やはく離点の位置は, ほぼ対称となって いることがわかる. NPR が 15 を下回ると図 6(d)(e) のようにはく離泡が大きくなり, はく離点と再付着点 の距離が離れていくことが確認できる.また，このと きのはく離点や再付着点の位置は非対称になってい る.この点については, 実験での可視化結果では検証 できないので, 次節で示す壁面圧力変動から検証する. そして NPR が 11.4 を下回ると, 図 6(e)のように非対 称に FSS とと変化した. ただし, FSS一遷移した NPR 


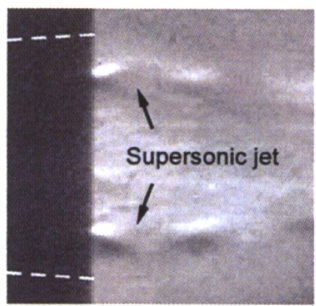

(a) NPR 100 (FSS)

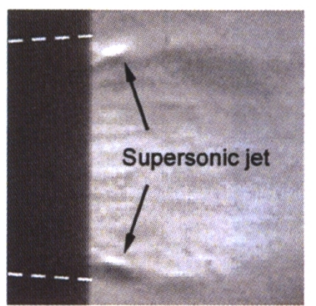

(b) NPR 80 (Transition into RSS)

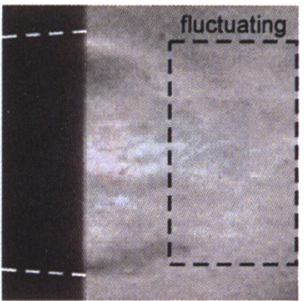

(c) NPR 20 (RSS)

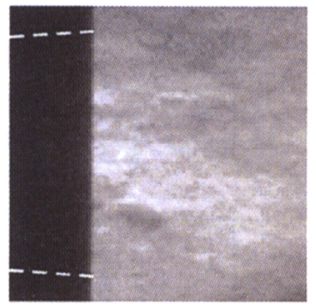

(d) NPR 18 (Transition)

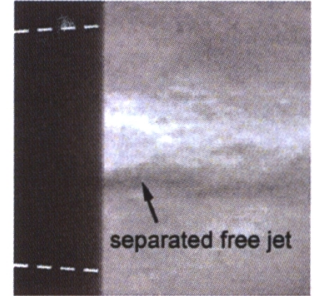

(e) NPR 17 (FSS)

Fig. 5 Schlieren pictures during shutdown

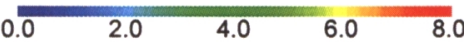

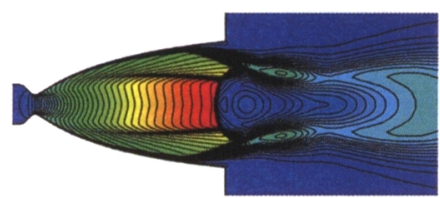

(a) $\mathrm{NPR}=100$

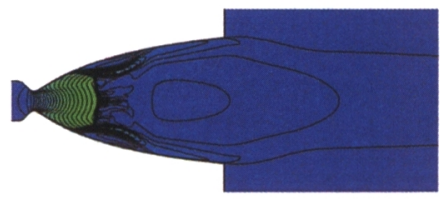

(d) NPR $=13.5$

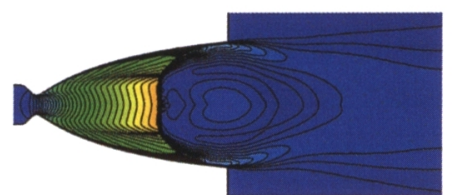

(b) $\mathrm{NPR}=39.5$

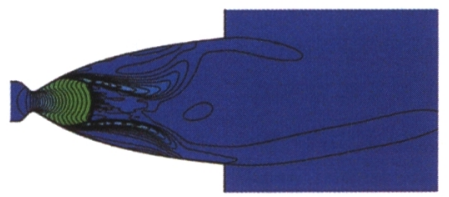

(e) $N P R=11.4$

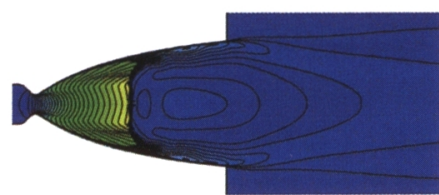

(c) $\mathrm{NPR}=23.1$

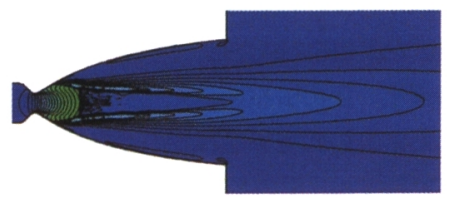

(f) $\mathrm{NPR}=10$

Fig.6 Mach number distribution

は実験結果(約 18) と異なっている. その後, FSS 一遷移 したジェットの形状は図 6(f)のように再びほぼ対称とな った.

以上より, 可視化結果と計算結果とを比較すると, 一 致した結果としては次の 2 点が挙げられる

1) FSS から RSS への変化時には流れの非対称性は小 さい.

2) RSS から FSS への変化時には流れは大きく非対称 となる。

相違点としては, RSS が発生する NPR の範囲が挙げら れる。.また, 数値計算の結果から, RSS の状態で NPR が特定の值に達すると, はく離泡が徐々に大きくなり,
再付着点がノズル出口に達したときに FSS へと変化す ることが判明した。

図 7 に非対称性が大きな NPR=11.4 のときのマッハ数 分布と速度ベクトルを示す. 図 7(a)はマッハディスク下 流の速度ベクトルを示している。この図より, はく離泡 内部の大きな循環領域が確認できる. 図 7(b)は, 図 7(a) 中に示した a-a'断面内の速度ベクトルである.この図を 見ると, はく離した超音速ジェット（マッ八数分布の色 が緑の部分）の形が大きく非対称となっていることがわ かる、また, 図中の左上の領域には, 対になった渦構造 が確認できる.ただし，この非対称性については NPR の変化に伴って向きが不規則に変化することはあった 


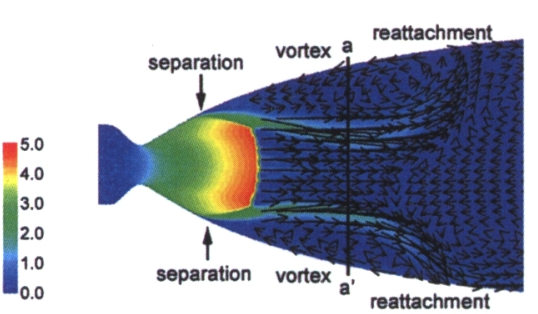

(a) Meridian section

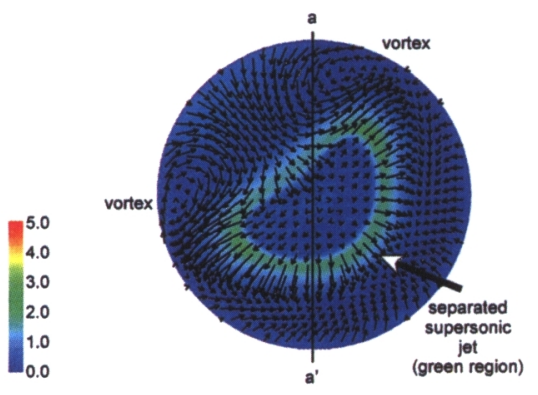

(b) Cross section "a-a""

Fig. 7 Velocity vector and Mach number distribution $(\mathrm{NPR}=11.4)$

が，周期的な回転などの変動は見られなかった．以上の ように, RSS から FSS 一の変化の過程では, はく離泡が 大きくなるとともに, その内部の流れは複雑な三次元構 造を持ち, 流れ場全体も非対称となることが判明した。 なお, RSS が発生していても流れ場がほぼ対称なときに は, はく離泡内部を含めて, ノズル内部の周方向速度成 分は小さく, ほぼ軸対称な流れであった。

$4 \cdot 2$ 壁面圧力の变化 図8に数值計算により得られた, 壁面上の圧力分布を示す. 図 8(a)は FSS から RSS 一遷移 した直後の図である.このとき, はく離点下流の再付着 点近傍では, 圧力が相対的に大きくなっていることがわ かる．以降，再付着点近傍の高圧領域を”a”之表す．ま たこのとき，等高線の分布を見るとわずかであるが非対 称になっていることも確認できる. 図 8(b)は NPR がさ らに低下したときの状態を表している. NPR の低下にし たがってはく離点や再付着点は上流へ移動している. 圧 力分布を見ると, 再付着点の下流に 2 つ目の圧力が大き な部分が形成されている.これはRSS の発生に伴って壁 面に付着した超音速ジェット内部にダイヤモンドショ ック構造ができているためであると考えられる，以降， この 2 つ目の高圧領域を”b”で表す，なお，このときに は圧力分布は，ほぼ対称になっている。なお，このとき には圧力分布は, ほぼ対称になっている。図8(c)はNPR がさらに下がり，RSS から FSS へ遷移する直前の図であ る.この図を見ると, 図 6, 図 7 でも示したように再付 着点が下流へ移動しているため, 高圧領域 a も下流へと

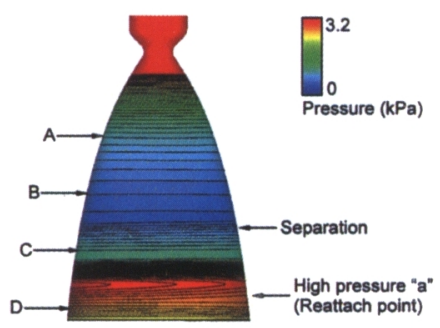

(a) $\mathrm{NPR}=39.5$

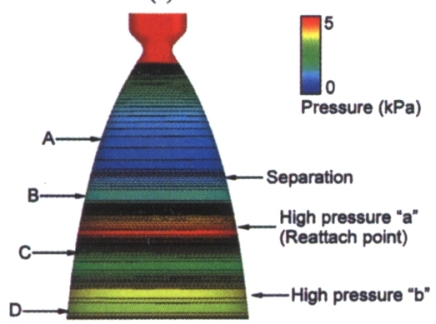

(b) $\mathrm{NPR}=23.1$

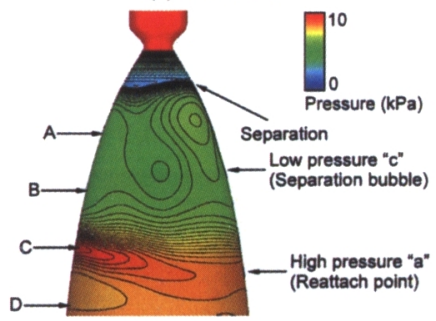

(c) NPR $=11.4$

Fig. 8 Wall pressure distribution

移動しており，高圧領域 $\mathrm{b}$ は消失している。またははく 離泡内部の圧力は高圧領域 $\mathrm{a}$ に比べて小さいので, 低圧 領域”c”と呼ぶことにする。 また，全体の壁面圧力分布 は大きく非対称となっている.

図 9 に実験, 計算での $\mathrm{A} 1, \mathrm{~B} 1, \mathrm{C} 1, \mathrm{D} 1$ の 4 点で得られた 壁面圧力の変化を示す. ただし, 後述のように周方向に 関しても非対称な結果が得られたが, 波形の主な特徵は 一致していたので,ここでは代表例を示した. 実験結果, 計算結果ともに点 B1 D1 では RSS が発生しているとき に幾つかの圧力の極大值が確認できる。これは, 図 8 で 示した高圧領域や低圧領域(はく離泡)の通過によるもの で，図中に示した $\mathrm{a}, \mathrm{b}, \mathrm{c}$ は，それぞれの計測点を通過し た高圧領域や低圧領域を表している。ここで，点 $\mathrm{C} 1, \mathrm{D} 1$ にaが 2 つるのは, 図 8(a), (b)で示したように, 高圧 領域 a が NPR の低下とともに上流入移動した後, 図 8(c) で示したように再び下流一移動するためである。なお， 実験結果については計算結果と比較し，これらを同定し た。 また, 計算結果では点 $\mathrm{B} 1$ で高圧領域 a が計測点を 通過した後に, 低圧領域 $\mathrm{c} か ゙$ 再び通過するため, 圧力低 

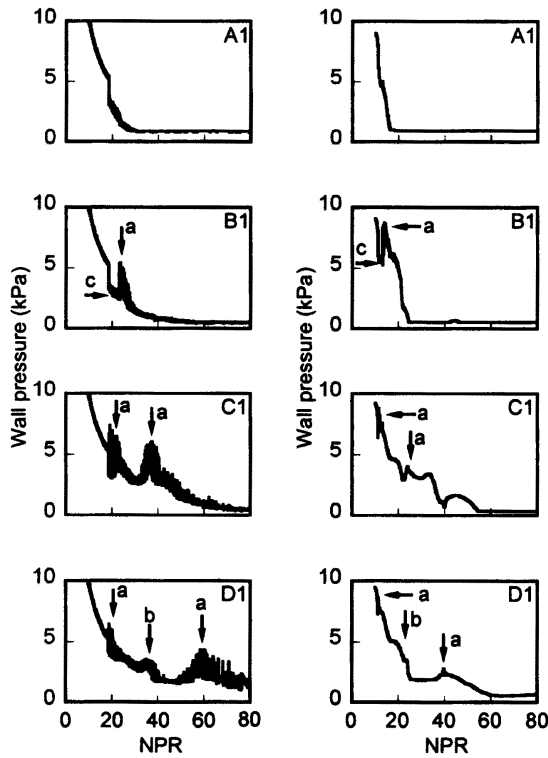

Fig. 9 Wall pressure versus NPR

(Left: measurement, right: simulation)

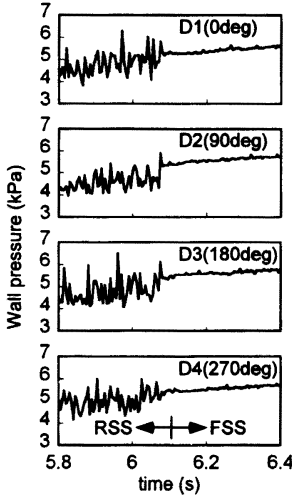

(a) Measurement

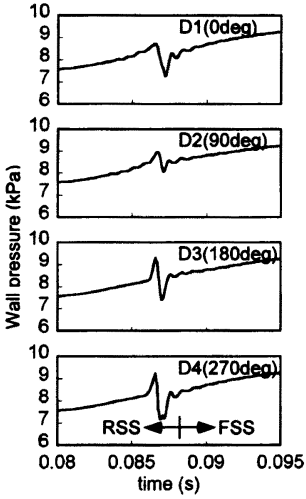

(b) Simulation
Fig. 10 Time history of wall pressure at point $D$

下が見られる.これは RSS から FSS へ遷移する過程で， 図 6(d), (e)や図 8(c)で示したように，はく離泡領域が大 きくなっていることによるもので，実験結果をみると同 様な波形が確認できることから, 図 6 で示したような, 数値計算から予測された過程を経て RSS から FSS へと 変化していることが確認できたといえる.

次に可視化結果で大きな非対称性が観察された RSS から FSS への変化時における，点 D1 から D4 の圧力の 時間履歴を図 10 に示す. まず，実験結果を見ると， RSS 発生下においては, 各時間で点 D1〜D4 全ての点の圧力 が一致せず，計算結果で予測されたように，非対称な圧 力分布になっていることが確認できる.ささらに，それぞ

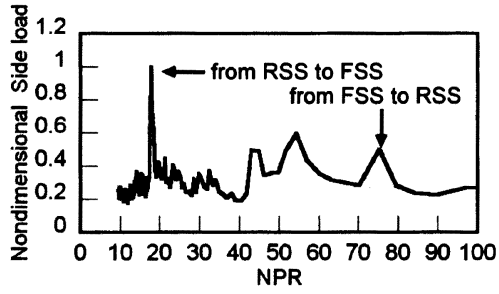

(a) Measurement (averaged value of 0.5 seconds)

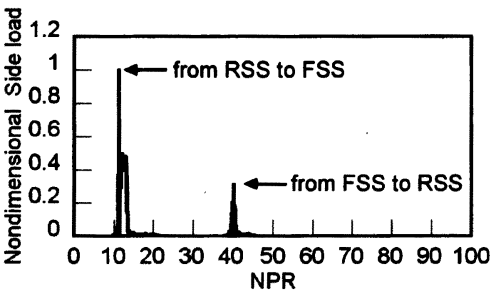

(b) Simulation

Fig. 11 Side load versus NPR

れの点で壁面圧力は，大きな振幅を伴って不規則に変動 しているが，これは高圧領域 $\mathrm{a}$ が通過する際に振動を伴 っていることを表していると考えられる.この振動につ いては, 周波数解析を行っても特定の周波数が得られな かった. よって流れの中に生じる小スケールの渦運動が 大きな要因であると推測される. 次に計算結果を見ると, RSS から FSSに変化する直前に高圧領域 a が通過するこ とに伴う圧力変動が 1 つ確認できる. しかし，実験結果 で見られたような不規則な変動は捕らえられていない. このように，高圧領域が通過する際に実験では不規則な 圧力変動を伴っているにもかかわらず, 計算では変動が 現れていないという傾向は, 図 9 で比較しても全ての NPR の範囲で同様である. この原因としては, 乱流モデ ルの影響が考えられる，つまり，本研究ではいわゆる RANS 系のモデルを採用しているため, 小さな渦構造は 全て渦粘性により拡散し，モデル化されている.したが って, 小スケールの渦構造に起因する不規則な変動は一 切再現されていないと考えられる. しかし,この変動に 関しては, 平均圧力に対する振幅の割合が大きく，ノズ ル内流れの非対称性や非定常性を解明する上では無視 出来ないと考えられる. よって, 詳細な調查は今後の課 題である.

$4 \cdot 3$ 横力の比較 図 11 に実験, 計算で得られた横力と NPR の関倸を示す． 縦軸の横力の值は, 実験結果, 計算 結果それぞれ, 最大值を 1 として無次元化した值となっ ている. また, 実験結果は 0.05 秒間ごとの平均値を示し ている. 実験結果については複数回計測した中で最も顕 著に横力が現れた結果を示した. まず実験結果を見ると， 
横力のピークが幾つか確認できる. 最も大きな横力は NPR が約 18 のときに発生しており, 可視化結果との対 応から RSS から FSS へ遷移する際に生じていることが わかる.ここには示していないがこのときの横力の時間 波形はパルス状となっていた. また, NPR が約 75 から 約 40 にかけて小さな横力が幾つか確認できるが，これ は FSS から RSS へ遷移したとき(NPR=75)や再付着点付 近にできる高圧領域の変動によるものである.このよう な横力の大きさに関する傾向は，可視化結果で見られた ように FSS から RSS への遷移過程では，流れ場がほぼ 対称であったのに対し， RSS から FSS へ遷移する際は， 流れが大きく乱れていたという傾向とも一致している. 横力の各方向の成分を調べたが, 横力が周方向に周期的 に変動している様子は見られず，パルス状の大きな力と して作用していた．また，全体を見ると，常に横力は 0 になっていない、これはひずみゲージから，不規則なノ ズルの振動や, 電気的なノイズによる微小な出力が常に 出ており, 高周波成分が周波数伝達関数により過大に評 価されたためである. 実験結果の再現性を確認するため に複数回実験を行ったが, RSS から FSS への遷移時の横 力は毎回確実に大きな値を示していたが, FSS から RSS への遷移過程での横力はほとんど確認できない例も多 く見られた. 次に計算結果を見ると，2つの横力のピー クが見られる. NPR が約 11 のときに見られる大きい方 のピークは RSS から FSS へ遷移する際の横力である.

一方 NPR が約 40 のときに見られる小さいほうの横力は FSS から RSS へ遷移する際に生じたものである.このよ うに, RSS から FSS へ遷移する際の横力が最大となり, FSS から RSS への遷移時にも小さな横力が生じている 傾向は，実験とよく一致している．また，実験と同様に 横力の方向に規則性はなくパルス状の力として作用し ていた．なお，壁面圧力同様に，計算では不規則な変動

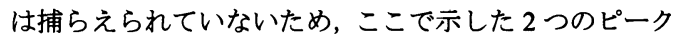
值以外はほぼ 0 となっている.

\section{5. 結}

本研究では圧縮率が $75 \%$ CTP ノズルを用いて，口 ケットノズルの停止時における過膨張流れについて実 験と 3 次元非定常数値計算の両面から, 流れ場の 3 次元 的性質や横力発生機構について調查した. 本研究で得ら れた知見を以下にまとめる.

実験結果，計算結果ともに，以下のような流れ場が観 察された. NPR が低下するに従い，はく離形態が FSS $\rightarrow \mathrm{RSS} \rightarrow \mathrm{FSS}$ 一と変化した. FSS から RSS へ変化する過 程では流れ場の非対称性は小さかったが，RSSから FSS 一変化する際は, 流れは大きく非対称となった.

RSS から FSS 一遷移する過程を計算結果から調べと ころ, NPR が一定の值に達すると，はく離泡が大きくな り, 再付着点がノズルの出口に達したときに FSS へと遷 移することが明らかとなった。このことは実験における 壁面圧力の変化からも確認された．また，このとき，は く離泡内部には複雑な 3 次元構造を持つことが判明した.

横力の発生については, FSS から RSS 一遷移する過程 およびRSS から FSS へ遷移する過程で確認された。

\section{文献}

(1) Hoffman, J. D., Design of Compressed Truncated Perfect Nozzles, AIAA Paper, 85-1172 (1985).

(2) Frey, M. and Hagemann, G, Restricted Shock Separation in Rocket Nozzles, Journal of Propulsion and Power, Vol. 16, No. 3, (2000), pp. 478-484.

(3) Watanabe, Y., et al., LE-7A Engine Nozzle Problems During the Transient Operations, AIAA Paper, 2002-3841 (2002).

(4) Frey, M., et al., Subscale Nozzle Testing at the P6.2 Test Stand, AIAA Paper, 2000-3777 (2000).

(5) Hagemann, G., et al., Appearance of Restricted Shock Separation in Rocket Nozzles, Journal of Propulsion and Power, Vol. 18, No. 3 (2002), pp. 577-584.

(6) Hagemann, G, et al., Scalability for Rocket Nozzle Flows Based on Subscale and Full-Scale Testing Journal of Propulsion and Power, Vol. 19, No. 3 (2003), pp. 321-331.

(7) Shimizu, T., et al., Internal Flow Computation of Rocket Engine Nozzles, $N A L S P-57$, (2003), pp. 166-171.

(8) Wang, T-S., Transient Three-Dimensional Analysis of Side Load in Liquid Rocket Engine Nozzles, AIAA Paper, 2004-3681 (2004)

(9) Yonezawa, K., et al., Suppression of Restricted Shock Separation in Overexpanded Rocket Nozzles, Transactions of the Japan Society of Mechanical Engineers, Series B, Vol. 71, No. 711 (2005), pp. 2702-2709.

(10) Wada, Y. and Liou, M-S., A Flux Splitting Schemes with High-Resolution and Robustness for Discontinuities, SIAM Journal on Scientific Computing Vol. 18, No. 3 (1997), pp. 633-657.

(11) Yamamoto, S. and Daiguji, H., Higher-Order-Accurate Upwind Schemes for Solving the Compressible Euler and Navier-Stokes Equations, Computers and Fluids, Vol. 22 (1993), pp. 259-270.

(12) Yoon, S. and Jameson, A., Lower Upper Symmetric Gauss Seidel Method for the Euler and Navier-Stokes Equations, AIAA Journal, Vol. 26, No. 9, (1988), pp. 1025-1026.

(13) Spalart, P. R. and Allamaras, S. R., A One-Equation Turbulence Model for Aerodynamic Flows, La Recherche Aerospatiale, Vol. 1 (1994), pp. 5-21.

(14) Menter, F. R., Two-Equation Eddy-Viscosity Turbulence Models for Engineering Applications, AIAA Journal, Vol. 32, No. 8 (1994), pp. 1598-1605.

(15) Takahashi, M., et al., Transient Flow Simulation of a Compressed Truncated Perfect Nozzle, AIAA Paper, 2001-3681 (2001). 